\title{
Post-formalist explanation of academic achievement: Exploring the contribution of John Ogbu and Joe Kincheloe
}

\section{Chetan Sinha}

Abstract: The present paper attempts to interrogate the existing approach to understand academic achievement in the mainstream educational psychology. The paper explores the persistent question of "why academic achievement gap" in the modern society from the cultural ecological and postformalist framework of John Ogbu and Joe Kincheloe respectively. As mainstream educational psychology limits its scope in the narrowed individualistic lens, paper suggests that dominant identity based curriculum, pedagogy and knowledge may concretize the psychological categories unless revolutionary efforts are made to transcend the boundaries. Thus, paper adopts critical interdisciplinary framework, rejecting positivistic metatheory as an only relevant approach in educational psychology.

Keywords: postformalism, educational psychology, academic achievement, India, Ogbu, Kincheloe.

One of the essential tasks of progressive educational praxis is the promotion of a curiosity that is critical, bold, and adventurous

Paulo Freire (1998)

The construction of equality and inequality in education mostly corresponded to the students' classroom performance and achievement. Equality was assumed to be the goal in terms of equal provision of opportunities 
and amenities to marginalized and disadvantaged children at par with their privileged counterpart. However, the academic achievement gap of student has varied behavioural and social consequences such as students failure (Ogbu, 1992; Steele, 2010), students dropout (Dreze \& Sen, 2008; Janosz, Blanc, Boulerice \& Tremblay, 2000), lack of motivation and interests (Carr $\&$ Dweck, 2011) and low academic identification (Ogbu, 2003; Voelkl, 1996). The reforms sanctioned to curb those inequalities nevertheless found to have their ontogenetical center under the same systematic discrimination on the part of schools based on their preference for formalists' domains supporting middle class values (see Collins, 2009; see also Portes, 2005). The above mentioned challenges placed before future educational reforms posed major obstacles towards equity and equality in education. Also, in the colonial countries, esample, India, the essence of colonial mindset in the name of modernity is still reflected in the form of competition, ability, achievement, aspirations and meritocracy discourses (see Kumar, 2009; Majumdar \& Mooij, 2012; Sinha, 2013). In an Indian educational context, these discourses were found to have elements of individual and cognitive factors which were socially represented among students, parents and teachers (see Sinha \& Mishra, 2015). The other notions of academic achievement and failure, however, were found to have less importance among those communities. Therefore, the representations and reification of dominant perspective of education as commonsensical knowledge on the historical time plane became the toothless ideology of mainstream educational system representing dominant identities (Moscovici \& Hewstone, 1983; Moscovici, 1998). This process of legitimization of education by the more dominant social group in the society, gradually, became part of the educational discourses.

Educating every child in India has become the essential need of nation as evident in number of policies such as Sarva Shiksha Abhiyaan, 2001, the right of children to free and compulsory education Act, 2009 etc. But according to Dubey (2010) these laws perpetuates the multilayer discriminatory school system in India and reduced the notion of education to functional literacy in the ambit of universal and compulsory education. The method to increment the motivational level of children and parents to continue education has contextual variants, such as, socioeconomic status, caste, gender, religion etc. These contextual variants shape the subjective understanding of one's status which either corresponds or not, in the decision making for seeking and continuing education. Recently, the World Bank report (2015) on 'mind, society, and behaviour' gave importance to the interrelation between human and social factors in better understanding and implementations of development policies specifically. However, their emphasis seems 
more on the contextual shaping of one's behavioural aspects where some of the prominent social contexts like construction of pedagogy and its representations were missing. The development of pedagogies creating effect for enhancing motivation of teachers and children and enriching classroom learning have oriented towards particular direction where middle class value system was mostly entertained in the name of universal solutions (see Sharma, 2005).

The present trends of innovative pedagogies had ordained the new mask in the name of critical approach where innovations seem to be reengineering of the same representations of education. It can be inferred that corresponding pedagogy to one's sociocultural experience had led to the resistance from the mainstream educational system in a subtle way due to emerging competitiveness in terms of fierce job market, globalized evaluation of one's identity and individualistic value system. Critical educational theorists like Joe Kincheloe and John Ogbu offered the divergent viewpoint moving beyond the mainstream notions of upper social class construction of curriculum and pedagogy. Although both the viewpoints critiqued the prevalent notions of ability, Kincheloe tradition was more inclined towards the postmodernist worldview of neo Marxism (see Kincheloe, 1995, 2001, 2005) whereas Ogbu's worldview was constructed within modernist notions of collective identity and struggle for political movement (Kincheloe \& Horn, 2007; Kincheloe, 1993, 1995, 1999, 2001). The former thrust on changing the classroom, whereas, latter points towards disidentification from the classroom and rejection of pedagogy embarking on White's cultural representations. Broadly, the emphasis was more on the critical pedagogy that stressed classroom as a site for political action and teachers as agent of change (see Kincheloe \& Steinberg, 1998; see also Sadovnik, Cookson \& Semel, 2013). Education involves identifying curriculum and efficient pedagogy creating ample space for improvement of academic achievement of students (see Govinda, 2003; see also Sleeter, Upadhyay, Mishra, \& Kumar, 2012). In this context, Batra (2005) expressed the need to include the voice and agency of teachers in framing of the curriculum in India. The aim of government, as discussed in various boards and committees, seem to be important for two reasons. First, educating children cent percent will wipe out the self stereotyped perception of inefficiency from government frontier institutions and secondly, political movements actively involved in the affirmative action and providing more socioculturally driven space in curriculum and pedagogy, for example, alternative form of education. It is evident that important issues such as culture, identity, context and situations which were not very prominent in earlier academic debates and disputation are actively discussed and understood in 
an Indian educational context (see Kumar, 2008). Educational problem are now understood through the interdisciplinary lens, ample work still need to be done to improve curriculum and pedagogical practices to enhance academic achievement of student from diverse background.

Recent reviews of academic achievement in the western psychological literature have emphasized the psychological processes underlying the academic achievement for example cognitive factors, metacognitive factors, motivational factors and contextual factors (see Winne \& Nesbit, 2010) but again the views were limited to the single and limited individualistic model of academic achievement in an Indian context (see Deshkal, 2010; Panda, 1988). More radical views about the concept of academic achievement were consciously ignored, since they were assumed to be questioning the dominant worldview of academic achievement, which was based on deficit assumption about agency and context. Some theoretical assumptions have questioned the single model of academic achievement and radically departure from the mainstream worldviews. In this context, present paper will try to position its argument from the cultural ecological and postformalist perspective highlighting the work of John Ogbu and Joe Kincheloe in an Indian context.

The first section presents a brief review of the concept of alternative framework of critical pedagogy highlighting the work of Ogbu and Kincheloe. In that there will be two sections dealing with the cultural ecological theory and its relevance to critical pedagogy and democratic educational psychology where Ogbu and Kincheloe positions will be discussed respectively. Then next section will try to search common points where Ogbu and Kincheloe collaborate. Thereafter, last two sections discussed the relevance of Ogbu and Kincheoe in an Indian context and outlining of historical legitimacy in education and practices which deals with the status of pedagogical practices in India, respectively. Together, present article try to discuss and integrate the framework and worlviews of John Ogbu and Joe Kincheloe, which were not only separately discussed in critical pedagogy and other social sciences literature, but also held a minority position in mainstream educational domain, especially in educational psychology.

\section{Alternative Framework to Critical Pedagogy: Ogbu and Kincheloe Approach}

The nature of disciplinary philosophy to which John Ogbu and Joe Kincheloe were inclined was anti-individualism and post-formalism, thus, criti- 
quing the mainstream educational psychology that comprises pedagogy and curriculum. The manner in which psychologism made individual processes dominant and powerful among the general population was not acceptable to these theorists. They highlighted the socio-political contexts under the influence of culture and history (see Nussbaum, 2013) in the explanation they offered to their criticism.

\section{Cultural-ecological theory and its relevance in critical pedagogy}

Ogbu empirically dealt with the issues of cultural frame of references, collective identity, and African-American perspective as a relevant benchmark to understand the role of diversity and bringing it back to the classroom in the form of critical pedagogy and diversity representations (See Osborne, 1996). He tried to link oppositional culture of African Americans with hegemonic power of White culture, which was observed to be located in the curriculum in a hidden rather than overt way, from social stratification point of view (see Bonikowski, 2004). Though Ogbu described cultural frame of references and collective identity separately, however, some authors (e.g., DeVos, 1984; Green, 1981; Holt, 1972) described the processes of opposition in the majority-minority group relationship as sustaining and reinforcing minorities' separate identity system (see Ogbu, 2008). Earlier, Spicer (1971) gave three reasons for the persistence of these minorities: a) individuals' beliefs in their personal affiliation with the meaning of certain symbols; b) the people's continued beliefs about unique historical events that forged their separate collective identity; and c) the group's definition of its historical destiny (p. 786). Accordingly, Ogbu emphasized on more ethnographic work needed to solicit the reality of African Americans, his contemporaries had taken both qualitative and quantitative approach to offer greater picture.

In an Indian context, diversity has different identity contingencies embedded in it and it is quite a situational phenomenon. For example, caste is the identity which is not colour based but it is the historical stratification on the basis of hierarchy of occupations linked to one's genealogy (see also Jodhka, 2012). This is no simplistic generalization of one's identity but its historical construction and representations which transformed one's consciousness of being a caste based social category. Also, this contingency has interlinked aspects which go into different domains of society, like, education, religions, social class etc. Studies showed how caste was represented in the curriculum and in what manner caste based stereotypes operated in an Indian society (see Hoff \& Pandey, 2006). Bringing Ogbu into these cultural contexts of Indian society may be associated to one event where Ogbu 
compared lower stratifications of African American with caste like society. However, originally caste was many times compared with race and thus casteism with racism (See Jodhka, 2012). Though, the meaning of identification is very much embedded into the subjectivities and experiences in different cultural contexts. Ogbu's emphasis on culturally relevant pedagogies in the multicultural context tried to bridge the gap between teachers and students' sociocultural perspectives. The thrust on the practice-theory dialectics provides a link to empower teachers as well as students (Osborne, 1996). The pedagogical structure, from Ogbu's theory, seems to be more corresponding to White or high status culture. Thus, the question is "does the identification with high status group as 'acting White' in African American context common for the other cultural context, for example, India'? However, this was evident in an oppositional cultural background as highlighted by Ogbu and Colleagues in African American context, but in an Indian context under the garb of colonial impact and modernity, the answer may be elusive.

The match and mismatch between teachers and students perspective were observed to be based on the complexities of social identities, the way projected social identities from the part of teachers were received by the students. Some of the literature pointed that categories based on the social identity may be de-categorized to break the message of mismatches in the perceptions of identity (see Gillespie, Howarth \& Cornish, 2012). For example, the studies comparing the role of discovery and direct pedagogical instructions found that the former was better in gaining broader and novel perspective about the task (see Bonawitz et al., 2001). Thus, the process of curriculum design and development of efficient pedagogical practices can be more representative by giving opportunities to students and parents from diverse background. On the similar line of Ogbu's cultural ecological theory, Chauhan (2014), in Indian context, adopted social representations theory of Moscovici (1988) to understand how government policies for education are represented by different categories of people such as parents, teachers, administrators etc. It was evident from the study that representations of policy may take a turn in terms of perceptions of different social categories. This cultural discontinuity in terms of policy givers and policy takers has major breakthrough when more democratic process is adopted by taking the view of diverse populations (see Burger, 1968).

The notions of collective identity and its social implications in the diverse society like India has multifaceted picture. The role of teachers and their pedagogic style depends upon many factors, such as education, cultural background, gender, caste etc. The pedagogic interventions at different lev- 
els of education starting from preprimary, primary, elementary, secondary and above has multiple causal factors behind. It most of the time depends upon the curriculum design, the limitations of policies and no appropriate method to deal with the diversified experience of students at different levels. For example, some of the literature pointed towards the psychological limitations of teachers and policy makers to treat education in terms of literacy attainments only (see Karlekar, 2004; see also Sinha, 2013). Thus, the stable academic achievement gaps in terms of reproduction of inequality such as low performance of rural students or low income school students as compared with high performances of urban and high income school students need to be loudly understood in the varieties of social contexts. Recent study observed that academic achievement and failure are characterized by multidimensional meanings (Sinha $\&$ Mishra, 2015). However, when it comes to the educational policies and its representations, the only factor that emerges out is cognitive and non cognitive agencies which are judged to be important marker in the academic performances. Therefore, the need is to understand students academic performance through the interdisciplinary lens by integrating disciplines such as history, ecology and psychology may give new hope to respond appropriately to the sustaining challenges of performance gap (see Foley, 2004). Earlier, the literature in India derived its argument from the existing social structure such as caste/class societies which had given way to the culture of dominance of worldviews calling traits and disposition as essential marker (see Dash \& Mohanty, 1996; Nambissan, 1996; Srivastava, 2009).

The stratifications of society into social class were found to contain the features of caste like cultural practices which was evident in the form of classism in various domains including education. Ogbu (1978) considered social class as a secondary with regard to more involuntary identity such as caste which has thicker social psychological boundary. However, some of the researches emphasized these boundaries as subjective and socially constructed (Roosens, 1989; Royce, 1982). The generation of hope to cross the boundary in the form of educational and social mobility with the novel tools of movements and political representations, can be considered as valid methodological input. The role of these methods transcends the perceptions of being located and driven by the same oppressive structure and provides new cognitive episodes for social change (see also Vaid, 2014). The attempt of Ogbu to understand ethnic/racial identity constructions and everyday ethnic/racial practices as cultural ecological give way to the emergence of viewpoint that considered these social categories as never fixed and inherited. Conversely, the effort to demonstrate the impermanency of 
the fixed identity of caste doesn't encouraged the revival of same stereotypical attribution giving solace to the permanence of meritocracy based on one's dominant gene, but to create a sense of belongingness through assertion of identity for emancipation and equality. This represented a major shift in the social sciences from an inherited biological notion of race to a culturally constructed notion of race/ethnicity, which was quite evident in the pedagogical and curricular structure (see Omi \& Winant, 1994; see also Hill, 2014) which goes beyond the politics of appearance. In this context, Ogbu pointed at the negative model of folk success, a pessimistic worldviews against the labour market, and persistent notions of occupation including lack of hope in the future social mobility aspects. The racially segregated society had contributed to the race based discriminations creating a sense of resistance to identify with the social norms and hence develop an oppositional culture consciously rejecting the persistent discriminations in the history of race struggle. Ogbu highlighted the transcendence of African Americans beyond the caste like cultures which was perceived as having permanent boundary and placed them into new form of secondary cultural practices, that is, to oppose the dominant culture of Whites. Thus, Ogbu offered a broader perspective to look into the terrains of pedagogy from critical viewpoint and created hope for emancipatory education across the world.

\section{Democratic educational psychology: Kincheloe position}

Kincheloe's theoretical position is based on Paul Freire's understanding of dominant course of mainstream educational psychology. Kincheloe (2007) offered a critical constructivist position to understand the student-teacher relationship under various socio-demographical contexts such social class, race, gender, sexuality, religion and language.

For example, he asked some of the relevant question such as,

"What is the purpose of schools?, How do we organize them for maximum learning and higher orders of cognitive activity?', What is the curriculum and how do we conceptualize it? How do we understand the relationship connecting mind, school, and society?" (Kincheloe, 2007; p. 855)

Kincheloe critically evaluated education and cognition where teacher in a very simplistic way passes the knowledge on students or learner, which Paul Freire, in his book 'Pedagogy of Oppressed', called as banking system of education. Learners or students are not simple organism who imitates what is shown to them but their cognition is situated in a context which 
they construct and co-construct in a socio-structural space. Moreover their consciousness of being is a dynamic process which is not a machine operating in terms of input and output as claimed by the behaviourists. Kincheloe (2007) expressed this as "consciousness and cognition cannot be separated from the sociohistorical context" (p. 862). The role of critical pedagogy and inclusive efforts had been observed to have positive effect on the self esteem and efficacy among students (Kincheloe, 1999). It was observed that agenda to critically evaluate ability frameworks in both the existing societal representations and research practices in education including pedagogy, which Kincheloe discussed under the broader framework of researcher worldviews referred as 'bricolage'.

The term 'bricolage' was discovered by Kincheloe from Kellner's (1995) and Denzin and Lincoln's (2000) work which was called as "the proto-articulation of a new rigor" in research with implications for scholarship and pedagogy" (see Kincheloe, 2001, p. 682). Also, he emphasized on the importance of rigorous education complemented with sensitivity and concern for human needs, with the goal of alleviation of human suffering (see Kincheloe, 1995; Kincheloe, 2005, see also Haslam \& Loughnan, 2014). Bricolage, according to Kincheloe (2001), "is concerned not only with multiple methods of inquiry but with diverse theoretical and philosophical notions of the various elements encountered in the research act" (p. 682). Kincheloe (2001) elaborated more on the process of bricolage by emphasizing the role of researchers as producer of knowledge has lived world political consequences, as they shape the ways we come to view the social cosmos and operate within it (Blommaert, 2008), drawing from numerous textual and critical strategies to 'interpret, criticize and deconstruct' the cultural artifacts under observation (Kellner, 1995).

Gallagher (2003) pointed that educational psychology was based on the assumption of technical rationality where its theory was considered as unbiased and neutral to any ideology. This hegemony of technical rationality as a broader framework for the assessment of students' ability was universalized. The main obstacles, till present, for dismantling inequality in education was the blind upsurge of modernity in the line of western concepts thereby neglecting the indigenous knowledge and socialization excellence provided by families and cultural context, forming an essential neglect of resources. The result was more narrowed and constrained development of research and outlook in the direction of interrogating local patterns, but instead effort was misguided in understanding the impact and the capacity to emulate classism and social structure of colonial context. Thus, it could 
be inferred that equality and equity in education depend upon grasping the complex nature of how social inequality is socially organized and sustained (Portes, 2005).

Taking a glance towards the reforms in educational sector, e.g., National Policy of Education (NPE) and National Curriculum Framework (NCF) in Indian context and No Child Left Behind (NCLB) in Western context, we may notice that despite the efforts in improving the quality of education and well being of children the all-encompassing achievement problems still persists. Attempts seem to strategically include maximum children into school for the purpose of increasing the statistic of children. However, the dropouts and other related problems pertaining to discrimination, lack of interest and poverty were interrogated maximally from the sociological point of view. The need arises to problematize the issues of pedagogy and curriculum and highlight the social psychological factors responsible for lack of equality in educational system.

The most common problems of academic achievement gap faced by students were often categorized as either genetic or socially driven. Even those who refused the dominant role of genetic influence metaphorized it in other caricatured forms. The historical forces which seem to shape the sociological imagination of students have been limited to epistemology derived from evolutionary framework. The reason behind the academic achievement gap was positioned under the individualistic genesis of vulnerability and deficiency among the low achiever. Thus, the observance of performance of students becomes the governing marker of students' achievement as well as nation development. Critical observation of school by students and their detachment from the forced entity of educational system was taken as something gone astray in the students' themselves and educational policy were designed on that basis.

\section{The Collaboration of Ogbu and Kincheloe}

The alternative worldviews of Ogbu and Kincheloe focuses on collective identity and its contingencies in educational domain and the antireductionist improvement of the system of education according to the needs of diverse students, respectively. The major concerns which these worldviews provided are the historical superiority of ability discourse which became more stable in the modern history of education. The reappearance of infallible ability and IQ based discourses attending to the dominant social identities was directly attacked by the theoretical positions of Ogbu and Kincheloe. 
The impact of empiricism on the basis of observable facts and its exploration by applying methodology of natural science characterized the nature of human science also. This systematic framing of human nature as driven by one's observable behaviour became a popular paradigm among the scientific community. Thus, the effort to raise the loopholes in the representations of causal factors behind human behaviour, especially, the efficiency of one's traits in the higher level achievement and appropriateness of divides in the society, have been critically highlighted by the theoretical frameworks of Ogbu and Kincheloe.

At the metatheoretical level Ogbu's theory of cultural ecological manifestation seems to be in congruency with Kincheloe position on critical pedagogy and postformal worldviews. Both discussed heavily on the existing structure of education, though, Kincheloe concern was more related to hardcore criticism of ability discourse and critical pedagogy addressing to the working class context. His work corresponds directly to existing class divides in education and is considered as a new revolution in educational psychology. Kincheloe as contrast to Ogbu concentrated more on curriculum and pedagogy under the broader umbrella of democratic educational psychology which was not limited to the single realm of ability but multidimensional aspects. Both theoretical structure of Ogbu and Kincheloe can be contrasted from Vygotsky (1978) and Piaget in terms of macro social aspects and its implication on changing behaviour. Vygotsky's work can be considered as microlevel structuration in which child's experience with familiar artefacts and use of objects was more prominent with his/her match or mismatch with existing school values. Kincheloe work in this context can be considered as more revolutionary and radical whereas Ogbu's work was more focused on highlighting the social context of Black in White's educational domain. However, prominence of structural aspects such as class status, roles and norms were obviously evident in the work of both Ogbu and Kincheloe. Overall, it can be positioned that Ogbu and Kincheloe offers a dynamic critical perspective for education and pedagogy at the schematic level which may also be understood more rigorously through the critical cultural constructivist lens.

\section{Relevance of Ogbu and Kincheloe in Indian Educational Context}

Education in India has historical connections and more appropriately a particular form of connections derived through specific archives and historiography. The contemporary trends in learning and teaching is derived from 
the ancient gurukul tradition of knowledge transferences. Gupta (2006) tried to explore the genesis of Indian pedagogical system from the Vedic traditions from where we may find the evidence for gurukul system. She tried to accommodate Vedic system of knowledge transference with Vygotsky's work under the postcolonial framework. Recently, Warner-Soderholm \& Kriger (2014) expressed their concern by placing classroom interaction in a deprived section, if the diversity and cultural issues such as religion in teacher-student are not well addressed (see also Singh, 1998). However, some of the scholars in India rejected Brahmanic traditions of knowledge impartation in the name of religion and purity which was considered as oppressive to disadvantaged section of the society such as lower caste and class (e.g. Guru, 2009; Jaspal, 2010; Thorat \& Newman, 2007). Despite much work done on minorities, based on caste and class in other disciplines, social psychology of education in India maintained its normal position of unbiasedness which was simply the denial of existing reality of inequality. It had tried to reflect on the issues like academic achievement gap but remained as an observer without crossing the boundaries of experiences and exploring subjective aspects of students and teachers. The necessity of exploring the students and teachers as actors' of their experience never came out with unique theory meant for the diverse culture like India. The estrangement between social psychology of education and indigenous psychology should be bridged under proper framework, such as critical constructivism. Thus, the framework offered by Ogbu and Kincheloe may be utilized for better understanding of pedagogies and curriculums in an Indian context.

\section{Reflections and Conclusion: Rethinking Formalism and Postformalism}

The present educational system has legitimized its mainstream ideology of bringing in middle class elements and value system, which inadvertently deprived the rights of the marginalized groups. However, it has been untenable approach to include the widely debated ideology into the mainstream education as new approach, as it was seen as unthinkable and oppressive on the part of victims. For example, positioning of different theoretical models into the national educational programs without being clear of the metatheoretical assumption of these approaches can be inconclusive and may possibly go beyond the agenda of open and democratic forms of education.

The formalist system of education as was criticized by Kincheloe and Ogbu were influenced by the psychometric tradition of measurement invariance and dominant worldviews which carried forward the mainstream 
educational value from long time even within the post positivistic era of scientific revolution. These dominant worldviews appropriated the tradition of inequality (Kincheloe, 1999). In this regard, Portes (2005) raised the question regarding the present status of education and persistent achievement gap. Thus, the need arises to investigate the primary reasons for the persistence of subtle inequity in educational outcomes which at the outset seems rational and democratic.

Indian school system, for example, has been the progeniture of the colonial mindset of meritocracy agenda derived by the monolithic value of cognitive psychology. Though the recent awareness programs facilitated through plays, writings or photography is in the processes of leaving gradual impact. As an exemplar, the recent movie in India 'Three Idiots' (2010) conveyed one important message to its audience that present system of education still embark its pedagogy on the banking style of education and thus, killing creativity among the students. Also, it brought into limelight the dominance and acceptance of particular discipline and education as legitimate representative of one's ability (e.g. studying technology, mainstream mathematics or engineering). These authoritarian prevalence and representations of education sustained the subjugation of the people who were either deprived of formal training because of their historically demoralized status or their differences in sociocultural and socialization experience from the values of mainstream pedagogy. After so many years of important educational revolution worldwide by the pioneers such as Vygotsky in Russia, Paulo Friere and Joe Kincheloe in Latin America, John Ogbu in North America, the education system silently subscribe to same functionalist approach, for example, 'education promotes equality'; 'schooling provided the means of socializing young adults into roles required by society'; 'schooling ensure social cohesion and harmony by moving us closer to equity and social justice'; and, above all, 'schooling accomplish this without prejudice to race, gender, or class'. This represents knowledge regarding the role of school in education. These aspects of 'academic achievement' have created much ado in the context of education and became part of educational dialogue. Other aspects which do not come across beneath the present understanding of academic achievement are the sociocultural influence on the cognitive structure of child. The formalist system of education is still the dominant force in the societal representations of academic achievement. Therefore, answer to the question that "Why one form of education which is prioritized in mainstream is always legitimized and valued and not others in the society?" is still framed under the dominant paradigms of cognitive ability. Therefore, it is becoming a fact that individuals' representations of society and any behaviour can be 
accumulated as societal input. The role of postformalists' in putting the opposite formulation of human agency, thus differentiating its approach from the formalistic assumption such as psychometrics in which students were seen in terms of their fitting/unfitting to the education system rather than fitting education to the diverse needs of the students. We ought to take theoretical and pedagogical stands against oppressive forms of discursively produced power hierarchies and out our own tacit theories about students and their abilities to learn, that help inform and construct these hierarchies and specific classroom learning environment at the first place.

From the viewpoint of Giroux (2010), as a contemporary of Kincheloe, pedagogy should be transformative going beyond the conformity, expanding the appropriation and imagination of knowledge in the form of critical reflection. However, Giroux (2010) expressed concern for transformative pedagogy being labeled as dangerous by the established system. According to Giroux (2010), critical pedagogy is also about recognizing the importance of different contexts and how these affect the conditions both for teaching and for interacting with students. Thus, it can be inferred that critical pedagogy fill up the missing link between formal and postformal education.

\section{References}

Andreouli, E., Howarth, C., \& Sonn, C. (2014). The role of schools in promoting inclusive communities in context of diversity. Journal of Health Psychology, 19 (1), 16-21. Batra, P. (2005). Voice and agency of teachers: Missing link in national curriculum framework. Economic and Political Weekly, 4347-4356.

Blommaert, J. (2008). Grassroots literacy. London: Routledge.

Bonawitz, E., Shafto. P., Gweon, H., Goodman, N. D., Spelke, E., \& Schulz, L. (2011). The double-edged sword of pedagogy: Instruction limits spontaneous exploration and discovery. Cognition, 120, 322-330.

Burger, H. G. (1968). "Ethno-pedagogy": A Manual in sensitivity, with techniques for promoting cross-cultural teaching by fitting ethnic patterns. Albuquerque, N.M.: South western Cooperative Educational Laboratory, Inc

Carr, P. B., \& Dweck, C. S. (2011). Intelligence and motivation. In R. J. Sternberg, $\&$ S. B. Kaufman (Eds.), The Cambridge handbook of intelligence (pp. 748-770). New York: Cambridge University Press.

Carr, P. B., \& Dweck, C. S. (2011). Intelligence and motivation. In R. J. Sternberg, $\&$ S. B. Kaufman (Eds.), The Cambridge handbook of intelligence (pp. 748-770). New York: Cambridge University Press.

Collins, J. (2009). Social reproductions in classrooms and schools. Annual Review of Sociology, 38, 33-48.

Dash, U. N., \& Mohanty, M. M. (1996). Schooling and cognition. Bhubaneswar: Centre of Advanced Studies in Psychology, Utkal University. 
Denzin, N. K., \& Lincoln, Y. S. (2000). Introduction. The discipline and practice of qualitative research. In N. K. Denzin, \& Y. S. Lincoln (Eds.), Handbook of qualitative research (pp. 1028). Thosand Oaks: Sage.

Deshkal (2010). Inclusive classrooms, social inclusion/exclusion and diversity perspectives, policies and practices. New Delhi: Deshkal Publication.

DeVos, G. A. (1984). Ethnic persistence and role degradation: An illustration from Japan. Unpublished manuscript presented at the American-Soviet Symposium on Contemporary Ethnic Processes in the USA and the USSR. New Orleans, LA.

Dreze, J., \& Sen, A. (2008). India development and participation. New Delhi: Oxford. Foley, D. (2004). Ogbu's theory of academic disengagement: Its evolution and its critics. Intercultural Education, 15 (4), 385-397.

Ford, R., \& Johnson, C. (1998). The perception of power: Dependence and legitimacy in conflict. Social Psychology Quarterly, 61 (1), 16-32.

Fordham, S., \& Ogbu, J. U. (1986). Black students' school success: Coping with the burden of "acting White." The Urban Review, 18(3), 176-206.

Freire, P. (1970). Pedagogy of the oppressed. New York: Herder and Herder.

French, J. R. P. Jr., \& Raven, B. H. (1959). The bases of social power. In D. Cartwright (Ed.), Studies in Social Power (pp. 150-67). Ann Arbor: University of Michigan.

Gallagher, S. (1999). An exchange of gazes. In J. L. Kincheloe, S. R. Steinberg \& L. E. Villaverde (Eds.), Rethinking intelligence: Confronting psychological assumptions about teaching and learning (pp. 69-84). Routledge: New York and London.

Gillespie, A., Howarth, C., \& Cornish, F. (2012). Four problems for researchers using social categories. Culture \& Psychology, 18 (3), 391-402.

Giroux, H. A. (2010). Dumbing down teachers: Rethinking the crisis of public education and the dismiss of the social state. Review of Education, Pedagogy and Cultural Studies, 32 (4-5), 339-381.

Govinda, R. (2003). Examinations and improving school quality: Reflections on Indian policies and practices. ANTRIEP Newsletter, 8, 10-15.

Gouldner, A. W. (1979). The future of intellectuals and rise of the new class. New York: Continuum Publishing Service.

Green, V. M. (1981). Blacks in the United States: The creation of an enduring people. In G. Castile and G. Kushner (Eds.), Persistent peoples: Cultural enclaves in perspective (pp. 69-77). Tucson: University of Arizona.

Gupta, A. (2006). Early childhood education, postcolonial theory, and teaching practices in India. Balancing Vygotsky and the Veda. New York: Palgrave Macmillan.

Guru, G. (2009). Humiliation. New Delhi: Oxford University Press.

Haslam, N., \& Loughnan, S. (2014). Dehumanization and infrahumanization. Annual Review of Psychology, 65, 399-423.

Hill, D. C. (2014). A vulnerable disclosure: Dangerous negotiations of race and identity in the classroom. Journal of Pedagogy, 5 (2), 161-181.

Hoff, K., \& Pandey, P. (2006). Discrimination, social identity, and durable inequalities. American Economic Review, 96 (2), 206-211.

Holt, G. S. (1972). Inversion in Black communication. In T. Kochman (Ed.), Rappin' and stylin'out (pp. 152-159). Chicago: The University of Illinois Press.

Howarth, C., \& Andreouli, E. (2014). 'Changing the context': Tackling discrimination at school and in society. International Journal of Educational Development, 41, 184-191. 
Hurd, I. (1999). Legitimacy and authority in international politics. International Organization, 53 (2), 379-408.

Janosz, M., Le Blanc, M., Boulerice, B., \& Tremblay, R. E. (2000). Predicting different types of school dropouts: A typological approach with two longitudinal samples. Journal of Educational Psychology, 92 (1), 171 - 190.

Jaspal, R. (2010). Caste, social stigma and identity processes. Psychology and Developing Societies, 23 (2), 27-62.

Karlekar, M. (2004). Paradigms of learning: The total literacy compaign in India. New Delhi: Sage.

Kasten, W. C. (1992). Bridging the horizon: American Indian belief's whole language learning. Anthropology \& Education Quarterly, 23 (2), 108- 119.

Kelman, H. C., \& Hamilton, V. L. (1989). Crimes of Obedience. New Haven, CT: Yale University Press.

Kincheloe, J. (1993). Toward a critical politics of teacher thinking: Mapping the postmodern. Westport, CT: Bergin \& Garvey.

Kincheloe, J. (1995). Meet me behind the curtain: The struggle for critical postmodern action research. In P. L. McLaren, \& J. M. Giarelly (Eds.), Critical theory and educational research (pp. 71-89). Albamy: State University of New York Press.

Kincheloe, J. L. (1999). The Foundations of a democratic educational psychology. In J. L. Kincheloe, S. R. Steinberg, \& L. E. Villaverde (Eds.), Rethinking Intelligence: Confronting psychological assumptions about teaching and learning (pp. 1 -26). Routledge: New York and London.

Kincheloe, J. (2001). Describing the bricolage: Conceptualizing a new rigor in qualitative research. Qualitative Inquiry, 7 (6), 679-692.

Kincheloe, J. L. (2005). Issues of power, questions of purpose. In J. L. Kincheloe, Classroom teaching: An introduction. NY: Peter Lang.

Kincheloe, J. L. (2007). Critical Constructivism and Postformalism: New Ways of Thinking and Being. In J. L. Kincheloe, \& R. A. Horn (Eds.), The Praeger handbook of education and psychology (Vol.4) (pp. 855-863). Westport: Praeger Publishing.

Kincheloe, J. L., \& Horn, R. A. (Eds.). (2007). The Praeger handbook of education and psychology (Vol. 4). Westport: Praeger Publishing.

Kincheloe, J.L., Steinberg, S., \& Villaverde, L.E. (1999). Rethinking intelligence: Confronting psychological assumptions about teaching and learning. NewYork: Routlege. Kumar, K. (2008). A pedagogue's romance: Reflections on schooling. New Delhi: Oxford University Press.

Kumar, K. Y. (2009). Understanding the education system: An eco-behavioural approach. Economic \& Political Weekly, 44 (23), 61-69.

Majumdar, M., \& Mooij, J. (2012). The marks race': India's dominant education regime and new segmentation. In C. Sleeter., S. B. Upadhyay., A. K. Mishra \& S. Kumar (Eds.), School education, pluralism and marginality: Comparative Perspectives (pp. 207-248). New Delhi: Orient Blackswan.

Moscovici, S. (1988). Notes towards a description of social representations. European Journal of Social Psychology, 18 (3), 195-209.

Moscovici, S. (1998). Social consciousness and its history. Culture and Psychology, 4, 411-429.

Moscovici, S., \& Hewstone, M. (1983). Social representations and social explana- 
tions: From the "naive" to the "amateur" scientist. In M. Hewstone (Ed.), Attribution theory: Social and functional extensions (pp. 98-125). Oxford: Blackwell.

Nambissan, G. B. (1996). Equity in education? Schooling of Dalit children in India. Economic and Political Weekly, 1011-1022.

Nussbaum, M. C. (2013). Political emotions: Why love matters for justice. Cambridge: The Belknap Press of Harvard University Press.

Ogbu, J. (1978). Minority education and caste: The American system in cross-cultural perspective. New York: Academic Press.

Ogbu, J. (1979). Social stratification and socialization of competence. Anthropology \& Education Quarterly, 10(1), 3-20.

Ogbu, J. U. (1992). Understanding cultural diversity and learning. Educational Researcher, 21(8), 5-14.

Ogbu, J. U. (1993). Differences in cultural frame of reference. International Journal of Behavioral Development, 16(3), 483-506.

Ogbu, J. U. (2003). Black American students in an affluent suburb: A study of academic disengagement. Mahwah, NJ: Lawrence Erlbaum.

Ogbu, J. U. (2003). Black American students in an affluent suburb: A study of academic disengagement. Mahwah, NJ: Lawrence Erlbaum.

Omi, M., \& Winant, H. (1994) Racial formation in the United States: from the 1960s to the 1980s ( $2^{\text {nd }}$ edn) (New York \& London, Routledge).

Panda, K. C. (1988). Social psychology of education. In J. Pandey (Ed.), Psychology in India: The state-of-the-art (pp. 279-337). New Delhi: Sage.

Portes, P. R. (2005). Dismantling educational inequality: A cultural-historical approach to closing the achievement gap. New York: Peter Lang

Roosens, E. (1989) Creating ethnicity: the process of ethnogenesis. Newbury Park: Sage. Royce, A. (1982) Ethnic identity: strategies and diversities. Bloomington: Indiana University Press.

Sadovnik, A. R., Cookson, P. W., \& Semel, S. F. (Eds.). (2013). Exploring education: An introduction to the foundations of education. New York: Routledge.

Said, E. (1977). Orientalism. London: Penguin.

Sleeter, C., Upadhyay. S. B., Mishra, A. K., \& Kumar, S (Eds.). (2012). School education, pluralism and marginality: Comparative Perspectives. New Delhi: Orient Blackswan.

Sinha, C. (2013). The sociocultural psychology as a postformal theory of academic achievement: An interrogation into the legitimacy of formal education. International Journal of Educational Psychology, 2 (2), 221-242.

Sinha, C., \& Mishra, A. K. (2015). The social representations of academic achievement and failure. Psychological Studies, 60 (2), 160-169.

Singh, A. (1998). Education and nation movement. In S. Bhattacharya (Ed.), The contested terrain: Perspectives on education in India (pp. 68-82). New Delhi: Orient Longman.

Spicer, E. H. (1971). Persistent cultural systems: A comparative study of identity systems that can adapt to contrasting environments. Science, 174, 795-800.

Srivastava, A. K. (2009). The dynamics of schooling. In G. Mishra (Ed.), Psychology in India: Advances in research. Vol. 2: Social and Organizational Process. New Delhi: Pearson. 
Steele, C.M. (2010). Whistling Vivaldi: How stereotypes affect us and what we can do. New York: W. W. Norton \& Company.

Stipek, J. D., \& Tannatt, L. (1984). Children's judge judgements of their own and their peers' academic competence. Journal of Educational Psychology, 76 (1), 75-84. Suchman, M. C. (1995). Managing legitimacy: Strategic and institutional approaches. Academy of Management Review, 20 (3), 571-610.

Thorat, S., \& Newman, K. S. (2007). Caste and economic discrimination: Causes, consequences and remedies. Economic and Political Weekly, 42 (41), 4121-4124.

Tyack, D., \& Tobin, W. (1994). The 'Grammar' of schooling: Why has it been so hard to change? American Educational Research Journal, 31 (3), 453-479.

Vaid, D. (2014). Caste in contemporary India: Flexibility and persistence. Annual Review of Sociology, 40, 391-410.

Voelkl, K. E. (1996). Identification with school. American Journal of Education, 105 (3), 294-318.

Vygotsky, L. (1 978). Mind in society: The development of higher psychological processes. M. Cole, V. John- Steiner, S. Scribner, \& E. Souberman (Eds). Cambridge, MA: Harvard University Press.

Warner-Soderholm, G., \& Kriger, M. (2014). The art of dealing with religious and cultural diversity in the classroom. International Journal of Business and Managemet, 9 (10), 149-160.

Wigfield, A., Eccles, J., Yoon, K., Harold, R., Arbreton, C., et al. (1997). Change in children's competence beliefs and subjective task values across the elementary school years: A three-year study. Journal of Educational Psychology, 89 (3), 451- 69. Winne, P. H., \& Nesbit, J. C. (2010). The psychology of academic achievement. Annual Review of Psychology, 61, 653-678.

\section{Author:}

Chetan Sinha, Ph.D.

Christ University

Department of Psychology

Hosur Road

Bangalore

Karnataka

560029

India

E-mail: sinchetan@gmail.com 